\title{
Juglone-Triggered Oxidative Responses in Seeds of Selected Cereal Agrosystem Plant Species
}

\author{
Hubert Sytykiewicz ${ }^{1 *}$, Agnieszka Kozak ${ }^{\mathbf{1}}$, Iwona Lukasik ${ }^{1}$, \\ Cezary Sempruch ${ }^{1}$, Sylwia Goławska ${ }^{1}$, Joanna Mitrus², Monika Kurowska ${ }^{1}$, \\ Katarzyna Kmieć ${ }^{3}$, Grzegorz Chrzanowski ${ }^{1}$, Bogumił Leszczyński ${ }^{1}$ \\ ${ }^{1}$ Department of Biochemistry and Molecular Biology, University of Natural Sciences \\ and Humanities, Siedlce, Poland \\ ${ }^{2}$ Department of Botany and Plant Physiology, University of Natural Sciences and Humanities, Siedlce, Poland \\ ${ }^{3}$ Department of Entomology, University of Life Sciences, Lublin, Poland
}

Received: 5 March 2018

Accepted: 16 May 2018

\begin{abstract}
Juglone (JU; 5-hydroxy-1,4-naphthoquinone) is an allelochemical synthetized by a wide range of Juglandaceae members. This compound evokes a wide array of detrimental effects in susceptible acceptor plants, including growth inhibition and impairments in the course of biochemical and physiological processes. Therefore, juglone may be considered as a potential bioherbicide in weed control in cereal crops. The purpose of our study was to determine the influence of JU treatment on the content of superoxide anion radical $\left(\mathrm{O}_{2}^{-}\right)$- sensitive and early marker of oxidative stress, and the activity of superoxide dismutase (SOD) - enzyme that functions as a crucial component of the first line antioxidative defense in seed tissues. In the study we tested seeds of four selected plant species of cereal agrosystem: corn poppy (Papaver rhoeas L.), corn cockle (Agrostemma githago L.), spring wheat (Triticum aestivum L., cv. Nawra), and spring oat (Avena sativa L., cv. Maczo). Additionally, the allelopathic influence of JU on seed germination of the studied plant species was investigated. The seeds were exposed to three examined juglone concentrations: $0.001,0.1$, and $10 \mathrm{mM}$ ( $4 \%$ methanoldeionized water solutions), whereas the control seeds were treated with aqueous methanolic solutions (4\%). Obtained results evidenced much more severe suppression of germination process and robust generation of superoxide anion radical in the tested weeds, compared to the cereals, and the crucial role of superoxide dismutase in limiting the juglone-induced oxidative stress in the studied seeds.
\end{abstract}

Keywords: juglone, superoxide anion radical, superoxide dismutase, spring wheat, spring oat, corn poppy, corn cockle

*e-mail: huberts@uph.edu.pl 


\section{Introduction}

Nowadays, the phenomenon of allelopathy is increasingly used in agriculture, especially in organic farming. So far, numerous examples of secondary metabolites applied in regulation of weed infestation in various agricultural crop systems have been reported [1-8]. A strong allelopathic potential of walnut trees (Juglandaceae members) which synthesize the phytotoxin juglone (JU; 5-hydroxy-1,4-naphthoquinone) has been reported [9-13]. This allelocompound is able to induce a broad range of severe morphological changes such as necrosis, chlorosis, suppression of seed germination, and seedling growth, and decrease the fresh and dry mass of shoots and roots of susceptible acceptor plants [14-16]. Juglone-affected damages in the plant tissues arise as a result of both biochemical and molecular alternations in the cells [17-18]. Juglone interrupts the course of several physiological processes such as cellular respiration and photosynthesis by interfering with the transport of electrons in mitochondrial and chloroplast membranes [16]. Moreover, this naphthoquinone may also disturb the uptake of nutrients through inhibiting the activity of plasma membrane $\mathrm{H}^{+}$-ATPase [19] and stimulate the lignification process [20], which is associated with the repression of plant growth. Additionally, studies performed by Chi and co-authors [21] evidenced that juglone treatment upregulated 827 genes in the rice root cells and simultaneously downregulated 142 genes linked to secondary metabolism. Sytykiewicz [17] also found that juglone applications caused significant alternations in expression of GstI gene (encoding glutathione transferase, GST) in maize coleoptiles and roots. Elevation in abundance of GSTI transcript in maize seedlings after 4-day JU exposure has been revealed, along with a decline in expression of the tested gene at 6 and 8 days of the experiments [17].

It has been hypothesized that juglone treatments may trigger excessive formation of reactive oxygen species (ROS) in plant cells [22]. Despite many allelopathic studies, the exact mode of action of 5-hydroxy-1,4-naphthoquinone has not yet been fully understood. Therefore, in the current work, an attempt was made to investigate the impact of this allelocompound on the generation of oxidative stress in the seeds of selected weeds and cereals occurring in the cereal agrosystem.

The purpose of the performed study was to establish the effect of JU treatments on levels of two commonly used and sensitive biochemical markers of oxidative stress in plant tissues: the content of superoxide anion radical $\left(\mathrm{O}_{2}^{-}\right)$and the activity of superoxide dismutase (SOD), in seed tissues of selected plant species of cereal agrosystem (i.e., corn poppy, corn cockle, spring wheat, and spring oat). In addition, germination of the studied seeds under JU exposure was compared.

\section{Material and Methods}

\section{Plant Materials and Conditions of the Experiment}

Seeds of four plant species of cereal agrosystem were tested (two weeds: corn poppy (Papaver rhoeas L.), corn cockle (Agrostemma githago L.), and two cereals: spring wheat (Triticum aestivum L., cv. Nawra) and spring oat (Avena sativa L., cv. Maczo)). The seeds were purchased from local grain companies: Strzelce Sp. z o.o., IHAR Group (Kończewice, Poland), PNOS (Ożarów Mazowiecki, Poland), and Przedsiębiorstwo Hodowlano-Nasienne W. Legutko (Jutrosin, Poland). Seed germination was performed under controlled conditions $\left(22 \pm 2^{\circ} \mathrm{C} /\right.$ day and $16 \pm 2^{\circ} \mathrm{C} /$ night, relative humidity $65 \pm 5 \%$, and photoperiod $16 \mathrm{~L}: 8 \mathrm{D}$ ) in an environmental chamber. The seeds of examined plants were placed on Petri dishes lined with Whatman No. 1 filter paper and moistened with JU solutions at 0.001, 0.1 , and $10 \mathrm{mM}$ (4\% methanol-deionized water). The examined concentrations of JU were selected on the basis of preliminary studies performed by our research group. The control seeds were treated with aqueous methanol solution (4\%). The seed germination process of the tested plant species was assessed after 8 days of continuous JU treatments, according to the protocol of Polish Norm: PN-R-65950 [23]. All the biotests were performed in four replications. Each round of the experiments comprised 100 seeds of the studied plant species per JU concentration.

\section{Biochemical Analyses}

The content of superoxide anion radical and the activity of superoxide dismutase in seeds of the investigated plants were determined at 1,2 , and 3 days of JU exposure. The analyses were conducted using a microplate UV-Vis spectrophotometer (Epoch, BioTek Instruments, Inc., USA). Chemical reagents used in the study were purchased from Sigma-Aldrich (Poland). The content of superoxide anion radical in the seed samples was quantified according to the method of Shah et al. [24], based on a reduction of nitrotetrazolium blue (NBT). The seeds $(0.5 \mathrm{~g})$ were homogenized in a mortar with $5 \mathrm{~cm}^{3}$ Na-phosphate buffer $(100 \mathrm{mM}$; $\mathrm{pH}=7.2$ ) containing $1 \mathrm{mM}$ of diethyldithiocarbamate (SOD inhibitor). The samples were centrifuged at $18,000 \times g$ for $15 \mathrm{~min}$. at $4^{\circ} \mathrm{C}$. The reaction mixture contained $1 \mathrm{~cm}^{3}$ of the supernatant and $0.5 \mathrm{~cm}^{3}$ $0.25 \mathrm{mM}$ NBT. The initial absorbance $\left(\mathrm{A}_{0}\right)$ at $\lambda=540 \mathrm{~nm}$ was measured. The reaction mixtures were incubated for $30 \mathrm{~min}$., and next the final absorbance $\left(A_{1}\right)$ was recorded at the same wavelength. Absorbance increase was calculated based on the following equation: $\Delta \mathrm{A}_{540}=\mathrm{A}_{1}-\mathrm{A}_{0}$. The content of superoxide anion radical was expressed as $\Delta \mathrm{A}_{540} \times \min ^{-1} \times \mathrm{g}^{-1}$ fresh weight (f.w.).

Superoxide dismutase activity was determined in accordance with the Beauchamp and Fridovich procedure [25], with minor modifications. The method 


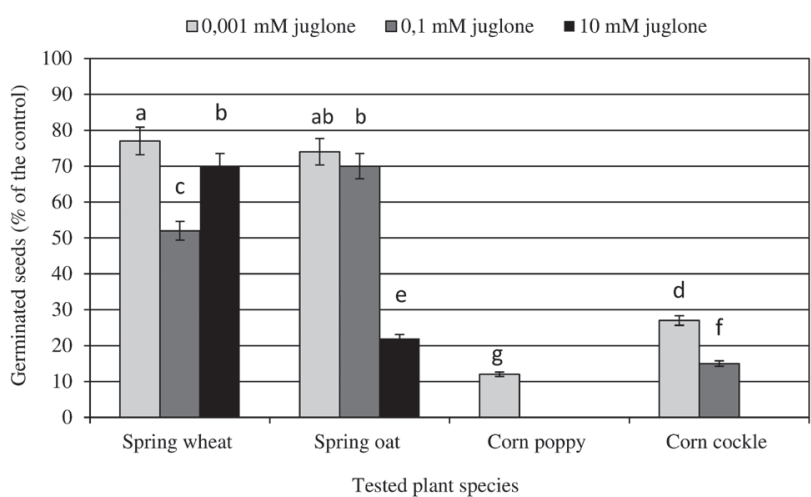

Fig. 1. The effect of juglone treatments on seed germination of tested plant species of cereal agrosystem after 8 days of experiments.

Control - germinated seeds of the examined plant species, untreated with juglone; different letters display significant differences between the mean values of germinated seeds ( $\mathrm{P}<0.05$; Tukey's test).

Table 1. Pearson's correlation coefficient ( $r$ ) calculated between tested juglone concentrations and number of germinated seeds after 8 days of biotests.

\begin{tabular}{|c|c|}
\hline Plant species & Seed germination \\
\hline Spring wheat & -0.233 \\
\hline Spring oat & -0.540 \\
\hline Corn poppy & $-0.992^{*}$ \\
\hline Corn cockle & $-0.904^{*}$ \\
\hline
\end{tabular}

*significant at $\mathrm{P}<0.05$

is based on inhibition of superoxide anion radical production in reaction with xanthine oxidase (XOD) and xanthine (XS). The seeds (portions of $0.2 \mathrm{~g}$ ) were homogenized in a mortar with $5 \mathrm{~cm}^{3}$ K-phosphate buffer $(50 \mathrm{mM} ; \mathrm{pH}=7.0)$ and then centrifuged at $10,000 \times g$ for $10 \mathrm{~min}$. (at $4^{\circ} \mathrm{C}$ ). Three types of the reaction mixtures were prepared: 1 ) test sample: $1.1 \mathrm{~cm}^{3}$ Tris- $\mathrm{HCl}$ buffer $(\mathrm{pH}=7.8), 0.1 \mathrm{~cm}^{3} \mathrm{XS}, 0.1 \mathrm{~cm}^{3} 0.25 \mathrm{mM}$ NBT, $0.1 \mathrm{~cm}^{3}$ of the supernatant, and $0.1 \mathrm{~cm}^{3}$ XOD $\left(1.3 \mathrm{U} \times \mathrm{mg}^{-1}\right.$ protein); 2) positive control: $1.1 \mathrm{~cm}^{3}$ Tris-HCl buffer, $100 \mathrm{~mm}^{3}$ XS, $0.1 \mathrm{~cm}^{3} \mathrm{NBT}$, and $0.1 \mathrm{~cm}^{3} \mathrm{XOD}$; 3) blank sample: $1.2 \mathrm{~cm}^{3}$ Tris-HCl buffer, $0.1 \mathrm{~cm}^{3} \mathrm{XS}$, and $0.1 \mathrm{~cm}^{3}$ NBT. The test sample and positive control were incubated for $25 \mathrm{~min}$. at $25^{\circ} \mathrm{C}$, then the absorbance at $\lambda=560 \mathrm{~nm}$ was measured. The unit of SOD activity (U) was defined as the amount of enzyme extract that inhibited the NBT reduction rate by $50 \%$. The specific SOD activity was expressed as $U \times \mathrm{mg}^{-1}$ protein.

\section{Statistical Analysis}

Results were displayed as mean $( \pm \mathrm{SD})$ from four randomized series of the biotests. Biochemical analyses were carried out in three technical replications.
STATISTICA 10 software (StatSoft, Poland) was employed to perform factorial ANOVA with consecutive Tukey's post-hoc test, which assessed the influence of three examined factors (i.e., plant species, juglone concentrations and exposure time) and their interactions on the content of superoxide anion radical and SOD activity in the seed tissues. In addition, Pearson's correlation coefficient (r) was evaluated in order to analyze relationships between JU concentrations and the number of germinated seeds.

\section{Results}

The tested treatments of juglone $(0.001,0.1$, and $10 \mathrm{mM}$ ) caused a decrease in the number of germinated seeds of all four examined plant species of the cereal agrosystem (i.e., spring wheat, spring oat, corn poppy, corn cockle); however, weed seeds were more sensitive to the studied allelochemical (Fig. 1, Table 1). The lowest applied concentration of JU $(0.001 \mathrm{mM})$ evoked only about a $25 \%$ decrease in the number of germinated seeds of the examined cereals, but germination process of the seeds of corn poppy and corn cockle was more severely suppressed $(88 \%$ and $73 \%$, respectively). After the application of $0.1 \mathrm{mM}$ $\mathrm{JU}$, at least $50 \%$ of cereal kernels germinated, whereas seeds of corn cockle germinated in only $15 \%$, but in the case of corn poppy seeds this process was completely arrested. The highest investigated concentration of JU $(10 \mathrm{mM})$ caused an inhibition of germination of wheat kernels by only $30 \%$ and oat by nearly $80 \%$, whereas the seeds of two studied weed species did not germinate.

Analyses carried out on seeds of the tested plants revealed that $\mathrm{JU}$ exposure triggered the generation of superoxide anion radical, compared to the non-treated control (Fig. 2, Table 2). The increases in the content of $\mathrm{O}_{2}^{--}$in the examined seeds were dependent on JU concentration, duration of exposure time and plant species. In most cases, the highest overproduction of analysed ROS form in cereal kernels occurred at $10 \mathrm{mM} \mathrm{JU}$, while in weed seeds at 0.001 or $0.1 \mathrm{mM} \mathrm{JU}$. In oat kernels, $12-48 \%$ increases in the content of $\mathrm{O}_{2}{ }^{-}$ after 1-day of JU application were found, but longer exposure to the tested naphthoquinone ( 2 and 3 days) resulted in higher elevations in production rate of the quantified radical $(20-218 \%$ in relation to the control). Additionally, the wheat kernels responded in $29-95 \%$ increments in the content of $\mathrm{O}_{2}^{-{ }^{-}}$at 1-day JU treatment, and further increases (36-151\%) were noted in the next two days of the biotests. In the case of the studied weeds, the highest level of $\mathrm{O}_{2}^{--}$was recorded in the corn cockle seeds in the first two days of JU treatments, whereas in corn poppy seeds it was on the last day of the experiments. Generally, averaging the impact of all tested concentrations of $\mathrm{JU}$ and all days of exposure, seed tissues of the weeds produced c.a. $45 \%$ more $\mathrm{O}_{2}{ }^{--}$ amount than the cereals compared to untreated controls. 
$\square$ control $\square 0,001 \mathrm{mM}$ juglone $\square 0,1 \mathrm{mM}$ juglone $\square 10 \mathrm{mM}$ juglone
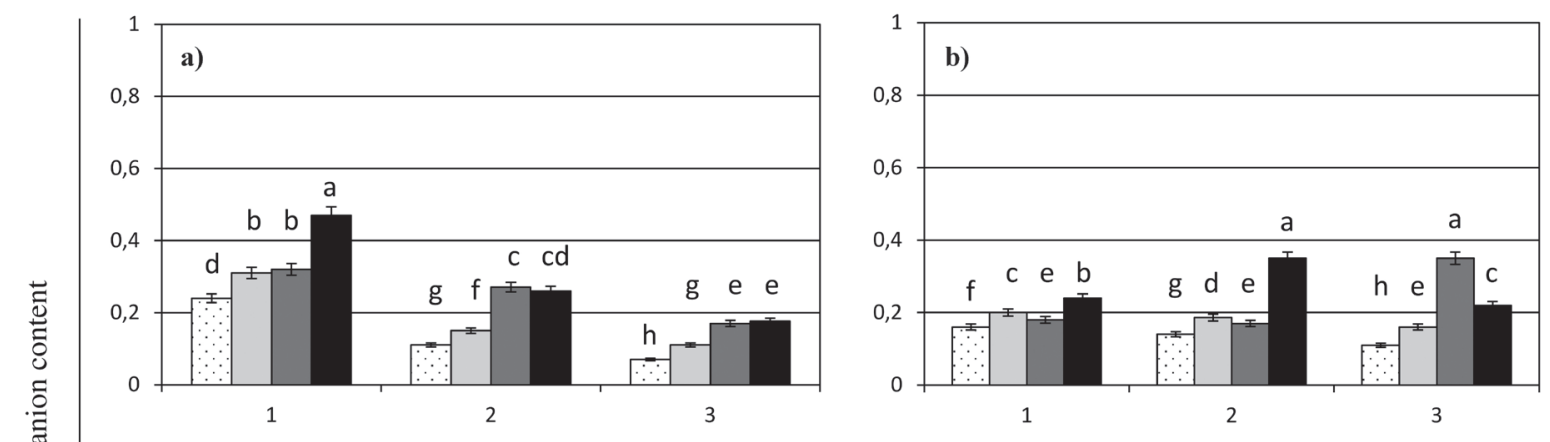

产
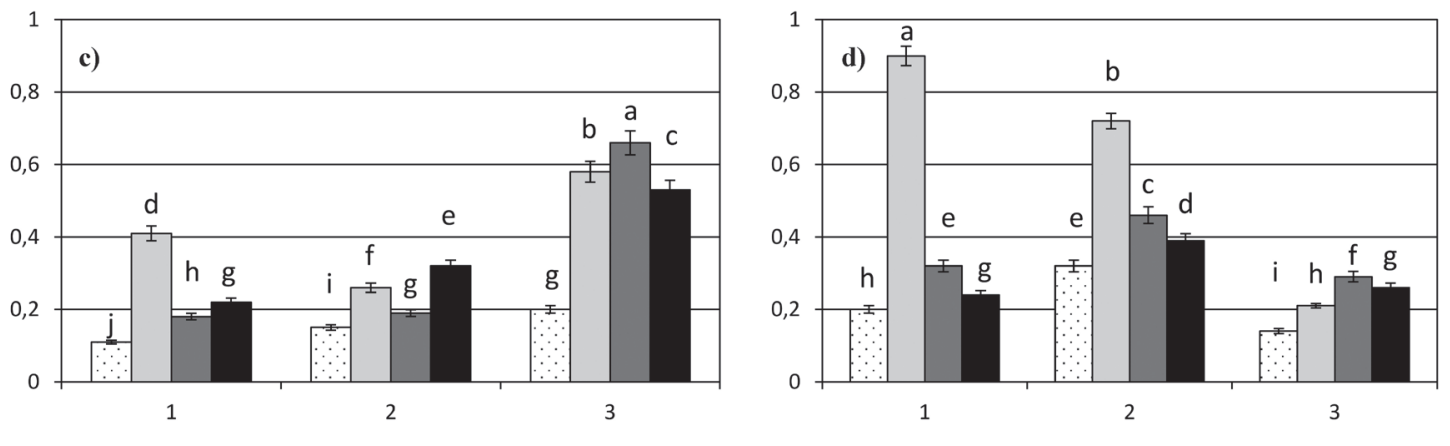

Juglone exposure time (days)

Fig. 2. Impact of juglone exposure on the content of superoxide anion radical $\left(\mathrm{O}_{2}^{--} ; \Delta \mathrm{A} \times \min ^{-1} \times \mathrm{g}^{-1} \mathrm{f}\right.$. w. $)$ in seeds of the examined cereal agrosystem plants after 1,2 , and 3 days of experiments.

a) spring wheat; b) spring oat; c) corn poppy; d) corn cockle; control - seeds of the tested plant species non-treated with juglone; different letters display significant differences in the content of $\mathrm{O}_{2}{ }^{-}$between seed tissues of the studied plant species $(\mathrm{P}<0.05$; Tukey's test).

Table 2. Three-factorial ANOVA results for the tested indicators (plant species, juglone concentrations, treatment time) and interactions on the activity of superoxide dismutase (SOD) and the content of superoxide anion radical $\left(\mathrm{O}_{2}^{-{ }^{-}}\right)$in seeds of the studied plant species (spring wheat, spring oat, corn poppy, corn cockle).

\begin{tabular}{|c|c|c|c|c|}
\hline \multirow{2}{*}{ Source } & \multicolumn{2}{|c|}{ SOD } & \multicolumn{2}{|c|}{$\mathrm{O}_{2}^{-{ }^{-}}$} \\
\cline { 2 - 5 } & $\mathrm{df}$ & $\mathrm{F}$ & $\mathrm{df}$ & $\mathrm{F}$ \\
\hline Plant species (S) & 3 & $834.2(* * *)$ & 3 & $355.4(* * *)$ \\
\hline Juglone concentrations (C) & 3 & $273.0(* * *)$ & 3 & $593.1(* * *)$ \\
\hline Treatment time (T) & 2 & $1,126.8(* * *)$ & 2 & $190.7(* *)$ \\
\hline $\mathrm{S} \times \mathrm{C}$ & 9 & $60.2(*)$ & 9 & $86.5(*)$ \\
\hline $\mathrm{C} \times \mathrm{T}$ & 6 & $91.9(*)$ & 6 & $65.4(*)$ \\
\hline $\mathrm{S} \times \mathrm{T}$ & 6 & $184.6(* *)$ & 6 & $4.0(\mathrm{~ns})$ \\
\hline $\mathrm{S} \times \mathrm{C} \times \mathrm{T}$ & 18 & $47.3(*)$ & 18 & $1.5(\mathrm{~ns})$ \\
\hline
\end{tabular}

$\mathrm{S}$ - spring wheat, spring oat, corn poppy, corn cockle; $\mathrm{C}-0$ (untreated), 0.001, 0.1 and $10 \mathrm{mM}$;

$\mathrm{T}-1,2,3$ days; $*(\mathrm{P}<0.05)$; ** $(\mathrm{P}<0.01)$; *** $(\mathrm{P}<0.001)$; df - degrees of freedom; ns - non-significant.

$\mathrm{JU}$ at the lowest tested concentration $(0.001 \mathrm{mM})$ caused about 4-fold higher formation of superoxide anion radical in the weed seeds than in the cereal kernels. In addition, weed seeds treated with $0.1 \mathrm{mM}$ JU produced a c.a. 2-fold amount of $\mathrm{O}_{2}^{--}$in comparison with the cereals. On the other hand, the highest concentration of juglone $(10 \mathrm{mM})$ stimulated nearly 2-times higher generation of the quantified free radical in the cereal kernels than in the weed seeds in relation to the controls.

JU significantly modified the activity of superoxide dismutase in the tested seeds, depending on concentration, exposure time, and studied plant species (Fig. 3, Table 2). One-day exposure to all examined JU concentrations resulted in a decline of SOD activity 


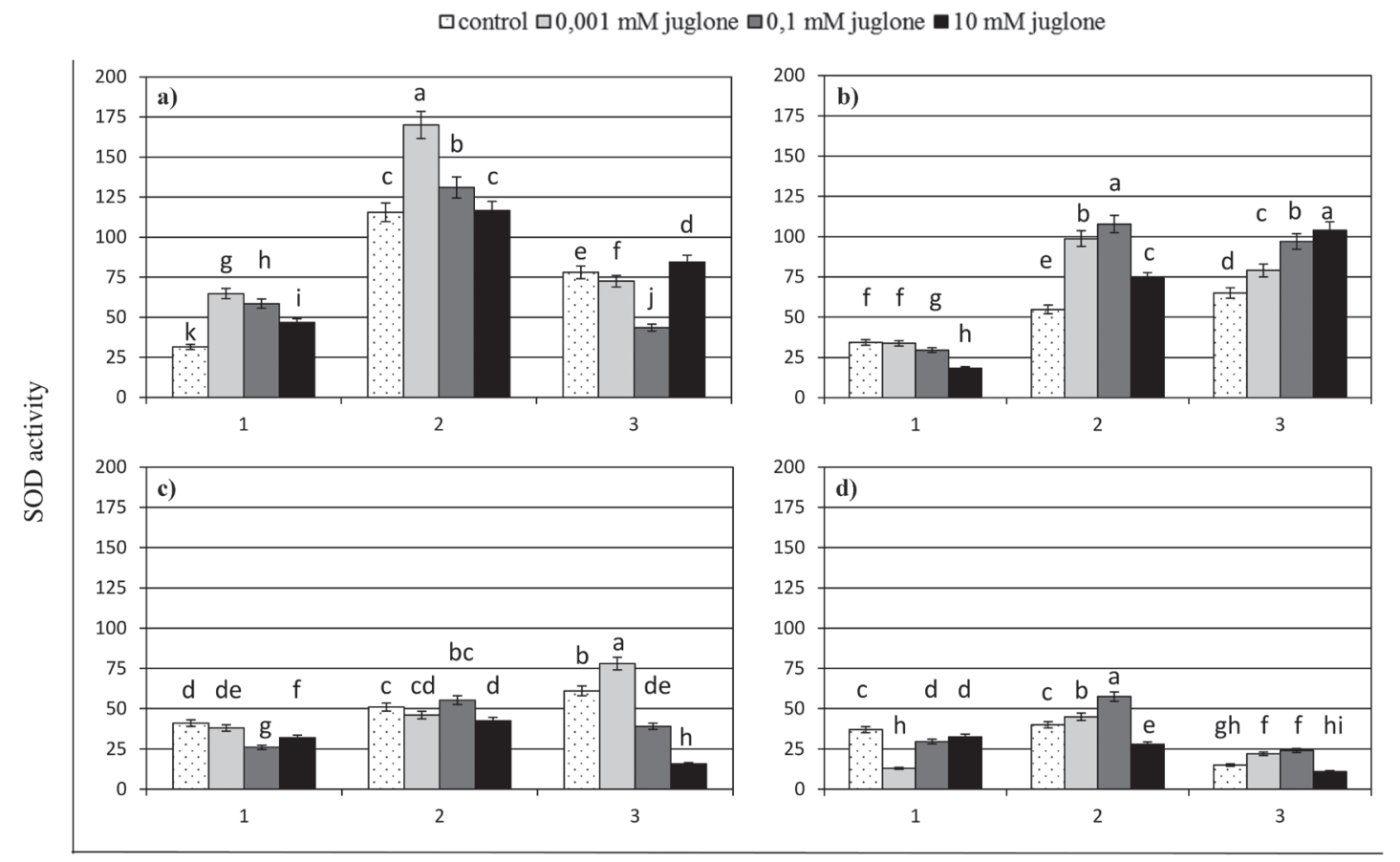

Juglone exposure time (days)

Fig. 3. Influence of juglone treatments on the activity of superoxide dismutase (SOD; $\mathrm{U} \times \mathrm{mg}^{-1}$ protein) in seeds of the tested cereal agrosystem plants after 1,2, and 3 days of biotests.

a) spring wheat; b) spring oat; c) corn poppy; d) corn cockle; control - seeds of the tested plant species untreated with juglone; different letters display significant differences in SOD activity between seed tissues of the studied plant species $(\mathrm{P}<0.05$; Tukey's test $)$.

in the seeds of three tested species: spring oat, corn poppy, and corn cockle $(2-47 \%, 7-35 \%, 12-65 \%$ decreases, respectively), but the reverse tendency in the enzyme activity was found in the wheat kernels (45-106\% increases). In most cases, JU applications for 2 or 3 days led to significant increments in the level of SOD activity in seed tissues of all tested plant species. Furthermore, it was established that lower juglone concentrations $(0.001$ and $0.1 \mathrm{mM})$ stimulated higher enhancement of SOD activity in examined seeds than a $10 \mathrm{mM}$ JU treatment. In addition, it should be underlined that $10 \mathrm{mM} \mathrm{JU}$ applications resulted in repression of the analysed enzyme activity in seed tissues of two studied weeds (corn poppy and corn cockle). The highest elevations in SOD activity occurred in cereal kernels (spring wheat - 97\% increase at 1-day exposure to $0.001 \mathrm{mM} \mathrm{JU}$; spring oat - $106 \%$ increase after 2 days at $0.1 \mathrm{mM} \mathrm{JU})$. In the case of investigated weed seeds, the maximal stimulation of SOD activity occurred after 3 days of JU exposure and reached much lower levels (corn poppy - $28 \%$ increase at $0.001 \mathrm{mM}$; corn cockle $-60 \%$ increment at $0.1 \mathrm{mM}$ ), in comparison with the control. Overall, the studied naphthoquinone caused an increase in the activity of SOD (the mean calculated for all investigated JU treatments) in seeds of spring wheat, spring oat, and corn cockle (29\%, 23\%, and $15 \%$, respectively), but conversely, SOD activity in corn poppy seeds was inhibited by $20 \%$ in relation to the control.

\section{Discussion}

The carried out research showed that two tested dicotyledonous weeds (i.e., corn poppy and corn cockle) were more sensitive to the influence of juglone than the examined monocotyledonous cereals (i.e., spring wheat and spring oat). The recorded changes occurred in both morphological and biochemical levels of the tested plants, which could have been caused by the induction of oxidative stress by the JU, leading to disturbances in the functioning of the cells. Previous studies on the impact of JU on germination of cereal kernels included such species as barley, maize, and wheat $[15,17,26]$. Terzi and Kocaçalişkan [27] elucidated that JU treatment (1 $\mathrm{mM}$ ) had no negative impact on germination of wheat kernels, but inhibited this process in barley kernels (c.a. 10\% reduction, relative to the control). Hao et al. [26] established that JU used at low concentrations (4 and $20 \mu \mathrm{M})$ accelerated germination of wheat, while at higher levels $(100-1250 \mu \mathrm{M})$ they inhibited this process. In other studies, it was shown that corn kernels treated with JU $(0.1$ and $10 \mu \mathrm{M})$ inhibited germination by about $10 \%$ and $20 \%$, respectively [17]. Terzi [27] ascertained that the use of $\mathrm{JU}$ at concentrations of 0.01-1.0 $\mathrm{mM}$ did not affect the germination of melon seeds, but caused a decrease in the number of germinated cucumber seeds from 20 to $50 \%$ (depending on the concentration). Other studies have shown that juglone $(0.1 \mathrm{mM})$ reduced germination of corn poppy seeds in 
$100 \%$, tomato in over $30 \%$, and dandelion in $70 \%$ [14]. Furthermore, Arabidopsis thaliana L. seeds did not germinate after exposure to juglone at concentrations of $0.5-1 \mathrm{mM}$ [28]. These results indicate a crucial role of interspecies differences in plant response to the presence of juglone and differences in the reaction of a given species depending on the used concentration of this allelochemical. It has been reported that the investigated allelochemical induced circumstantial disturbances in cell division, elongation processes, and cell death [16, 29-30]. Terzi and Kocaçalişkan [15] revealed that exogenous application of JU (1 $\mathrm{mM})$ markedly declined the length of wheat roots and shoots by $80 \%$ and $62 \%$, respectively. In addition, the length of barley roots and shoots has been reduced by $48 \%$ and $81 \%$, respectively. Matok [14] also observed that JU at 0.01 and $0.1 \mathrm{mM}$ concentrations completely inhibited the growth of winter wheat roots and shoots by over $60 \%$, and decreased their biomass (by $55 \%$ and $95 \%$, respectively). Furthermore, Hejl and Koster [19] noted that JU applications reduced the length of corn roots and shoots (25\% and $20 \%$ declines, respectively) and decreased the dry mass of seedlings by $40 \%$. In addition, Sytykiewicz [17] showed that even low concentrations of JU $(0.1-10 \mu \mathrm{M})$ reduced the fresh weight of maize seedlings $(15-53 \%)$ and also inhibited root growth (8-45\%). Exposure to this naphthoquinone at 0.001 and $0.05 \mathrm{mM}$ concentrations also resulted in a reduction of the root length of rice by $10 \%$ and $80 \%$, respectively [21]. Morphological changes caused by juglone were also studied for a few weed species [31]. JU treatments (1.15-5.74 $\mathrm{mM})$ led to a strong inhibition of seedling growth and decline in the biomass in a concentrationdependent manner. The tested naphthoquinone at the highest concentration evoked an inhibition of seedling growth of the pink corylus (Lamium amplexicaule L.) by $70 \%$ and the field osteoarthritis (Cirsium arvense /L./ Scop.) by $80 \%$. There was also a decrease in the fresh mass of the pink corylus (65\%) and the field osteoarthritis (99\%), compared to the controls [31].

In the current study, it was strongly evidenced that JU exposure induced significant pro-oxidative responses in the tested seeds. However, higher increases in the content of superoxide anion radical occurred in the examined weed seeds in comparison with wheat and maize kernels. Conversely, the studied cereal seeds responded to considerably greater enhancement in SOD activity, evidencing more efficient antioxidative responses compared to the weed ones. Overproduction of highly toxic and reactive $\mathrm{O}_{2}{ }^{--}$radicals may lead to oxidative damage to the structures of nucleic acids, proteins, lipids, and sugars, as well as initiate the mechanism of programmed cell death in plant tissues $[16,32]$. Superoxide dismutases (SODs) comprise a diverse group of plant enzymes involved in the first line of anti-oxidative defense reactions. SOD isoforms are localized in several cell compartments (e.g., mitochondria, peroxisomes, chloroplasts, cytosol) and catalyze dismutation reaction of superoxide anion radical to less toxic hydrogen peroxide $\left(\mathrm{H}_{2} \mathrm{O}_{2}\right)$ and molecular oxygen [33-34]. Despite the content of superoxide anion radicals and activity of the superoxide, dismutase are largely considered as sensitive markers of pro- and antioxidative responses, respectively, in plants subjected to adverse environmental stimuli [22, 32-41]. The effects of JU exposure on the level of these parameters in the seeds of cereal or weed species are largely unknown.

Recently, Nowicka et al. [42] revealed that JU treatments $(20 \mu \mathrm{M})$ stimulated the formation of lipid hydroperoxides and decreased the content of prenyllipid antioxidants in microalga Chlamydomonas reinhardtii in relation to the control. Furthermore, the formation of semiquinone radicals in JU-stressed cells with the application of electron paramagnetic resonance (EPR) spectroscopy were confirmed. Furthermore, Kurtyka et al. [22] documented JU-induced increases in the amount of hydrogen peroxide, in parallel with augmentation in SOD and catalase activities in maize coleoptiles. It has been found that JU exposure increased the accumulation of $\mathrm{H}_{2} \mathrm{O}_{2}$, especially in the cytosol and cell wall spaces in maize tissues. According to Chen and coworkers [43], pretreatment with proline (Pro), alleviated allelochemical stress in JU-exposed tobacco seedlings. Moreover, it was found that JU applications increased the expression of two genes (ornithine aminotransferase and pyrroline-5-carboxylate synthetase) and participated in Pro biogenesis, as well as downregulating the proline dehydrogenase gene linked to catabolic turnover of this amino acid in tobacco roots. The involvement of proline in overcoming JU-induced stress in plant cells has been suggested. Additionally, a few reports have elucidated that the transport of JU in soil may be significantly enhanced by fungal hyphae, hence modifying its biological effects [44-45]. On the other hand, results of numerous in vitro studies evidenced a strong antimicrobial and antiparasitic impact of JU or extracts derived from walnut tissues [46-52]. The use of allelopathy phenomenon in crop production is gaining increased recognition, particularly in organic farming. One of the important tasks of the integrated agronomic systems is protection of biodiversity and the use of natural compounds to combat plant diseases, pests, and weed infestation in the crop cereals. Examples of plant species (or secondary metabolites derived from their tissues) used for regulation of weed infestations in a variety of agricultural crops have been widely described [18, 53-55]. However, only in-depth insight into the basis of both biochemical and molecular mechanisms of allelochemical interactions between plants comprise a rationale application of allelopathy in agrosystems.

\section{Conclusions}

It has been evidenced that JU applications have caused a markedly higher suppression of germination process of the examined weed seeds (i.e., corn poppy and corn cockle) in comparison with the cereal ones 
(i.e., spring wheat and spring oat). In general, we found a substantially greater overproduction of superoxide anion radical and lesser increment in SOD activity in JU-treated weed seeds compared to the cereals. The allelopathic potential of JU toward the seeds of corn poppy and corn cockle is associated with triggering oxidative stress. The obtained results indicated that JU at lower concentrations may be potentially used as the bioherbicide in weed management strategies, including cereal agrosystems. However, further comprehensive studies should be performed.

\section{Acknowledgements}

Our research was financially supported by the National Science Centre of Poland under grant No. 2016/21/B/NZ9/00612.

\section{Conflict of Interest}

The authors declare no conflict of interest.

\section{References}

1. KATO-NOGUCHI H. Rice allelopathy and momilactone. Pak. J. Weed Sci. Res. 18, 289, 2012.

2. LAM Y., SZE CH.W., TONG Y., NG T.B., TANG S.CH.W., HO J.CH.M., XIANG Q., LIN X., ZHANG Y. Research on the allelopathic potential of wheat. Agricult. Sci. 3, 979, 2012. DOI: $10.4236 /$ as. 2012.38119.

3. SHARMA M., SATSANGI G.P. Potential allelopathic influence of sunflower (Helianthus Annuus L.) on germination and growth behavior of two weeds in-vitro condition. Int. J. Biotechnol. Bioeng. Res. 4, 421, 2013.

4. JAWAD M., KHAN N., KHAN H., ZARIN S., ARIFULLAH K.N., ADIL M., REHMAN S., KHAN R. Bio-herbicidal potentials of wheat (Triticum aestivum L.) on some of its major weeds. Pak. J. Weed Sci. Res. 19, 79, 2013.

5. ABDELMIGID H.M., MORSI M.M. Cytotoxic and molecular impacts of allelopathic effects of leaf residues of Eucalyptus globulus on soybean (Glycine max). J. Genet. Engineering Biotech. 15, 297, 2017. DOI: 10.1016/j. jgeb.2017.08.005.

6. LATIF, S., CHIAPUSIO, G., WESTON, L.A. Chapter two - allelopathy and the role of allelochemicals in plant defence. Adv. Bot. Res. 82, 19, 2017. DOI: 10.1016/ bs.abr.2016.12.001.

7. KAUR S., KAUR R., CHAUHAN B.S. Understanding crop-weed-fertilizer-water interactions and their implications for weed management in agricultural systems. Crop Prot. 103, 65, 2018. DOI: 10.1016/j.cropro.2017.09.011.

8. MWENDWA J.M., BROWN W.B., WU H., WESTON P.A., WEIDENHAMER J.D., QUINN J.C., WESTON L.A. The weed suppressive ability of selected Australian grain crops; case studies from the Riverina region in New South Wales. Crop Prot. 103, 9, 2018. DOI: 10.1016/j. cropro.2017.09.003.

9. LESZCZYŃSKI B., MATOK H., SYTYKIEWICZ H. Basic aspects of walnut allelopathy: from field to biomolecules. LAP LAMBERT Academic Publishing, Saarbrücken, Germany, 2012.

10. COSMULESCU S., TRANDAFIR I., NOUR V. Seasonal variation of the main individual phenolics and juglone in walnut (Juglans regia) leaves. Pharmaceut. Biol. 52, 575, 2014. DOI: $10.3109 / 13880209.2013 .853813$.

11. NOUR V., TRANDAFIR I., COSMULESCU S. Optimization of ultrasound-assisted hydroalcoholic extraction of phenolic compounds from walnut leaves using response surface methodology. Pharmaceut. Biol. 54, 2176, 2016. DOI: 10.3109/13880209.2016.1150303.

12. NOUR V., TRANDAFIR I., COSMULESCU S. HPLC determination of phenolic acids, flavonoids and juglone in walnut leaves. J. Chromatogr. Sci. 51, 883, 2013. DOI: 10.1093/chromsci/bms180.

13. RAO G., SUI J., ZHANG J. Metabolomics reveals significant variations in metabolites and correlations regarding the maturation of walnuts (Juglans regia L.). Biol. Open 5, 829, 2016. DOI: 10.1242/bio.017863.

14. MATOK H. Effect of selected secondary plant metabolites of walnut (Juglans regia L.) on seed germination. Ph.D. thesis, University of Natural Sciences and Humanities, Siedlce (Poland), 2010 [In Polish].

15. TERZI I., KOCAÇALIŞKAN I. The effects of gibberellic acid and kinetin on overcoming the effects of juglone stress on seed germination and seedling growth. Turk. J. Bot. 34, 67, 2010. DOI: 10.3906/bot-0905-17.

16. BABULA P., VAVERKOVA V., POBORILOVA Z., BALLOVA L., MASARIK M., PROVAZNIK, I. Phytotoxic action of naphthoquinone juglone demonstrated on lettuce seedling roots. Plant Physiol. Biochem. 84, 78, 2014. DOI: 10.1016/j.plaphy.2014.08.027.

17. SYTYKIEWICZ H. Expression patterns of glutathione transferase gene (GstI) in maize seedlings under juglone-induced oxidative stress. Int. J. Mol. Sci. 12, 7982, 2011. DOI: $10.3390 / \mathrm{ijms} 12117982$.

18. CHENG F., CHENG Z. Research progress on the use of plant allelopathy in agriculture and the physiological and ecological mechanisms of allelopathy. Front. Plant Sci. 6, 1020, 2015. DOI: 10.3389/fpls.2015.01020.

19. HEJL A.M., KOSTER K.L. Juglone disrupts root plasma membrane $\mathrm{H}^{+}$-ATPase activity and impairs water uptake, root respiration, and growth in soybean (Glycine max) and corn (Zea mays). J. Chem. Ecol. 30, 453, 2004.

20. BÖHM P.A.F., BÖHM F.M.L.Z., FERRARESE M.L.L., SALVADOR V.H., SOARES A.R., FERRARESE-FILHO O. Effects of juglone on soybean root growth and induction of lignification. Allelopathy J. 25, 465, 2010.

21. CHI W.-CH., FU S.-F., HUANG T.-L., CHEN Y.-A., CHEN CH.-C., HUANG H.-J. Identification of transcriptome profiles and signaling pathways for the allelochemical juglone in rice roots. Plant Mol. Biol. 77, 591, 2011. DOI: 10.1007/s11103-011-9841-6.

22. KURTYKA R., POKORA W., TUKAJ Z., KARCZ W. Effects of juglone and lawsone on oxidative stress in maize coleoptile cells treated with IAA. AoB Plants 8, plw073, 2016. DOI: $10.1093 /$ aobpla/plw073.

23. PROTOCOL PN-R-65950. Seed material - seed testing methods. The Polish Committee for Standardization, Warsaw (Poland), 1994. [In Polish]

24. SHAH K., KUMAR R.G., VERMA S., DUBEY R.S. Effect of cadmium on lipid peroxidation, superoxide anion generation and activities of antioxidant enzymes in growing rice seedlings. Plant Sci. 161, 1135, 2001. 
25. BEAUCHAMP C.O., FRIDOVICH I. Superoxide dismutase: improved assays and an assay applicable to acrylamide gels. Anal. Biochem. 44, 276, 1971.

26. HAO F., ZHAI M-Z., WANG Y., YAN T. Allelopathic effects of juglone on the growth of wheat seedlings and seed germination. Acta Bot. Boreal.-Occid. Sin. 32, 518, 2012.

27. TERZI I. Allelopathic effects of juglone and decomposed walnut leaf juice on muskmelon and cucumber seed germination and seedling growth. Afr. J. Biotech. 7, 1870, 2008.

28. REIGOSA M.J., PAZOS-MALVIDO E. Phytotoxic effects of 21 plant secondary metabolites on Arabidopsis thaliana germination and root growth. J. Chem. Ecol. 33, 1456, 2007.

29. MYLONA P.V., POLIDOROS A.N., SCANDALIOS J.G. Antioxidant gene responses to ROS-generating xenobiotics in developing and germinated scutella of maize. J. Exp. Bot. 58, 1301, 2007. DOI: 10.1093/jxb/erl292.

30. POBORILOVA Z., OHLSSON A.B., BERGLUND T., VILDOVA A., PROVAZNIK I., BABULA P. DNA hypomethylation concomitant with the overproduction of ROS induced by naphthoquinone juglone on tobacco BY-2 suspension cells. Environ. Exp. Bot. 113, 28, 2015. DOI: 10.1016/j.envexpbot.2015.01.005.

31. TOPAL S., KOCAÇALIȘKAN I., ARSLAN O., TEL A.Z. Herbicidal effects of juglone as an allelochemical. Phyton 46, 259, 2007.

32. PRASAD A., KUMAR A., MATSUOKA R., TAKAHASHI A., FUJII R., SUGIURA Y., KIKUCHI H., AOYAGI S., AIKAWA T., KONDO T., YUASA M., POSPÍŠIL P., KASAI S. Real-time monitoring of superoxide anion radical generation in response to wounding: electrochemical study. PeerJ 5, e3050, 2017. DOI: $10.7717 /$ peerj.3050.

33. SHEN Y., LI J., GU R., YUE L., WANG H., ZHAN X., XING B. Carotenoid and superoxide dismutase are the most effective antioxidants participating in ROS scavenging in phenanthrene accumulated wheat leaf. Chemosphere 197, 513, 2018. DOI: 10.1016/j.chemosphere.2018.01.036.

34. SYTYKIEWICZ H. Differential expression of superoxide dismutase genes in aphid-stressed maize (Zea mays L.) seedlings. PLoS One 9, e94847, 2014. DOI: 10.1371/ journal.pone.0094847.

35. SYTYKIEWICZ H., CHRZANOWSKI G., CZERNIEWICZ P., SPRAWKA I., ŁUKASIK I., GOŁAWSKA S., SEMPRUCH C. Expression profiling of glutathione transferase genes in Zea mays (L.) seedlings infested by cereal aphids. PLoS One 9, e111863, 2014. DOI: 10.1371/journal.pone.0111863.

36. YANG L.Y., YANG S.L., LI J.Y., MA J.H., PANG T., ZOU C.M., HE B., GONG M. Effects of different growth temperatures on growth, development, and plastid pigments metabolism of tobacco (Nicotiana tabacum L.) plants. Bot. Stud. 59, 5, 2018. DOI: 10.1186/s40529-0180221-2.

37. TAHERI P, KAKOOEE T. Reactive oxygen species accumulation and homeostasis are involved in plant immunity to an opportunistic fungal pathogen. J. Plant Physiol. 216, 152, 2017. DOI: 10.1016/j. jplph.2017.04.018.

38. ARFAOUI A., EL HADRAMI A., DAAYF F. Pretreatment of soybean plants with calcium stimulates ROS responses and mitigates infection by Sclerotinia sclerotiorum. Plant Physiol. Biochem. 122, 121, 2018. DOI: 10.1016/j.plaphy.2017.11.014.
39. HANAKA A., LECHOWSKI L., MROCZEK-ZDYRSKA M., STRUBIŃSKA J. Oxidative enzymes activity during abiotic and biotic stresses in Zea mays leaves and roots exposed to $\mathrm{Cu}$, methyl jasmonate and Trigonotylus caelestialium. Physiol. Mol. Biol. Plants 24, 1, 2018. DOI: 10.1007/s12298-017-0479-y.

40. LIU G., LIU J., ZHANG C., YOU X., ZHAO T., JIANG J., CHEN X., ZHANG H., YANG H., ZHANG D., DU C., LI J., XU X. Physiological and RNA-seq analyses provide insights into the response mechanism of the Cf10-mediated resistance to Cladosporium fulvum infection in tomato. Plant Mol. Biol. 2018. DOI: 10.1007/s11103-0180706-0. [Epub ahead of print]

41. LIU W., XU F., LV T., ZHOU W., CHEN Y., JIN C., LU L., LIN X. Spatial responses of antioxidative system to aluminum stress in roots of wheat (Triticum aestivum L.) plants. Sci. Total Environ. 627, 462, 2018. DOI: 10.1016/j. scitotenv.2018.01.021. [Epub ahead of print]

42. NOWICKA B., ŻĄDŁO A., PLUCIŃSKI B., KRUKA J., KUCZYŃSKA P. The oxidative stress in allelopathy: Participation of prenyllipid antioxidants in the response to juglone in Chlamydomonas reinhardtii. Phytochemistry 144, 171, 2017. DOI: 10.1016/j.phytochem.2017.09.012.

43. CHEN S.-Y., CHI W.-C., TRINH N. N., CHENG K.T., CHEN Y.-A., LIN T.-C., LIN Y.-C., HUANG L.Y., HUANG H.-J., CHIANG T.-Y. Alleviation of allelochemical juglone-induced phytotoxicity in tobacco plants by proline. J. Plant Interact. 10, 167, 2015. DOI: 10.1080/17429145.2015.1045946

44. ACHATZ M., MORRIS E.K., MÜLLER F., HILKER M., RILLIG M.C. Soil hypha-mediated movement of allelochemicals: arbuscular mycorrhizae extend the bioactive zone of juglone. Funct. Ecol. 28, 1020, 2014. DOI: $10.1111 / 1365-2435.12208$.

45. ACHATZ M., RILLIG M.C. Arbuscular mycorrhizal fungal hyphae enhance transport of the allelochemical juglone in the field. Soil Biol. Biochem., 78, 76, 2014.

46. SYTYKIEWICZ H., CHRZANOWSKI G., CZERNIEWICZ P., LESZCZYNSKI B., SPRAWKA I., KRZYŻANOWSKI R., MATOK H. Antifungal activity of Juglans regia (L.) leaf extracts against Candida albicans isolates. Pol. J. Environ. Stud. 24, 1339, 2015. DOI: $10.15244 /$ pjoes/34671.

47. ZMANTAR T., MILADI H., KOUIDHI B., CHAABOUNI Y., BEN SLAMA R., BAKHROUF A., MAHDOUANI K., CHAIEB K. Use of juglone as antibacterial and potential efflux pump inhibitors in Staphylococcus aureus isolated from the oral cavity. Microb. Pathog. 101, 44, 2016. DOI: 10.1016/j.micpath.2016.10.022.

48. ARASOGLU T., DERMAN S., MANSUROGLU B., YELKENCI G., KOCYIGIT B., GUMUS B., ACAR T., KOCACALISKAN I. Synthesis, characterization and antibacterial activity of juglone encapsulated PLGA nanoparticles. J. Appl. Microbiol. 123, 1407, 2017. DOI: 10.1111/jam.13601.

49. ARASOGLU T., MANSUROGLU B., DERMAN S., GUMUS B., KOCYIGIT B., ACAR T., KOCACALISKAN I. Enhancement of antifungal activity of juglone (5-hydroxy-1,4-naphthoquinone) using a poly(D,L-lacticco-glycolic acid) (PLGA) nanoparticle system. J. Agric. Food Chem. 64, 7087, 2016. DOI: 10.1021/acs.jafc.6b03309.

50. SHANG X.F., LIU Y.Q., GUO X., MIAO X.L., CHEN C., ZHANG J.X., XU X.S., YANG G.Z., YANG C.J., LI J.C., ZHANG X.S. Application of sustainable natural resources in agriculture: acaricidal and enzyme inhibitory activities of naphthoquinones and their analogs against Psoroptes 
cuniculi. Sci. Rep. 8, 1609, 2018. DOI: 10.1038/s41598-01819964-0.

51. MALEITA C., ESTEVES I., CHIM R., FONSECA L., BRAGA M.E.M., ABRANTES I., DE SOUSA H.C. Naphthoquinones from walnut husk residues show strong nematicidal activities against the root-knot nematode Meloidogyne hispanica. ACS Sust. Chem. Engin. 5, 3390, 2017. DOI: 10.1021 /acssuschemeng. $7 \mathrm{~b} 00039$.

52. ESTEVES I., MALEITA C., FONSECA L., BRAGA M.E.M., ABRANTES I., DE SOUSA H.C. In vitro nematicidal activity of naphthoquinones against the rootlesion nematode Pratylenchus thornei. Phytopathol. Mediterr. 56, 127, 2017. DOI: 10.14601/Phytopathol_ Mediterr-19314.

53. SOŁTYS D., KRASUSKA U., BOGATEK R., GNIAZDOWSKA A. Allelochemicals as bioherbicides
- present and perspectives. (In:) Herbicides - Current Research and Case Studies in Use. PRICE A.J., KELTON J.A., editors; Rijeka, Croatia, InTech Publisher; 20, 517, 2013. DOI: $10.5772 / 56185$.

54. DURÁN A.G., CHINCHILLA N., MOLINILLO J.M., MACÍAS F.A. Influence of lipophilicity in $O$-acyl and $O$-alkyl derivatives of juglone and lawsone: a structure activity relationship study in the search for natural herbicide models. Pest Manag. Sci. 74, 682, 2018. DOI: 10.1002/ps.4764.

55. MÜLLER A., FINK M. Studies on allelochemical and mineral compounds for sustainable weed control in a pavement filler from brick recycling material. J. Hort. Sci. Biotechnol. 92, 214, 2017. DOI: 10.1080/14620316.2016.1252699. 
